\title{
Halina MARLEWICZ
}

Jagiellonian University in Kraków, Poland

halina.marlewicz@uj.edu.pl

\section{HETEROTOPIAN CITY}

\section{KHUSHWANT SINGH AND HIS DELHI: $A$ NOVEL $L^{1}$}

ABSTRACT The essay is an attempt to analyse Khushwant Singh's Delhi: A Novel as a literary work in which topography and existence, life and literature entwine. The essay is divided into three parts, each part has a particular focus. The part entitled Indeterminate Zone concentrates on the paratext in an attempt to see how it channels reader's anticipation with regard to the content of the book. In the second part: Zone of the City: the image of Delhi in its chosen (re)constructions within the novel is examined. Here, particular attention is paid to the reconstruction of space and time within the novel. The last section of the paper, Zone of the Body speaks of the body and the symbolic roles it plays within the novel.

Keywords: Khushwant Singh, Delhi: A Novel, city studies, hijra

\footnotetext{
Some critical analyses of the novel include: R.K. Bajpai, P. Dixit, 'Khushwant Singh's Delhi: A Novel as History' in R. S. Pathak (ed.), Indian Fiction of the Nineties, New Delhi 1997, pp. $41-46$ (Creative New Literatures Series, 15); I. Bhatt (ed.), Fictional World of Khushwant Singh, New Delhi 2002, chapters 13-17 (Creative New Literatures Series, 53); R. Chopra, 'Fiction as Social History: A Study of Khushwant Singh's Novels,' IUP Journal of English Studies, Vol. 8, No. 2 (2013), pp. 59-77; R. Gupta, 'Humour in Khushwant Singh's Delhi,' The Quest, Vol. 14, No. 1 (2000), pp. 42-49; M. Jha, 'The Fictional Technique of Khushwant Singh: A Case Study of Delhi' in K.N. Awasthi (ed.), Contemporary Indian English Fiction: An Anthology of Essays, Jalandhar 1993, pp. 115-122; O.P. Mathur, 'Khushwant Singh's Delhi - A Gloss on History' in idem, The Modern Indian English Fiction, New Delhi 1993, pp. 184-191; P. Rao, 'Khushwant Singh's Delhi: Between History and Passion,' Indian Scholar, Vol. 15, No. 1 (1993), pp. 33-44.
} 
In the center of Fedora, that gray stone metropolis, stands a metal building with a crystal globe in every room. Looking into each globe, you see a blue city, the model of a different Fedora. These are the forms the city could have taken if, for one reason or another, it had not become what we see today. Italo Calvino, Invisible Cities

\section{INTRODUCTION}

The topographical turn in contemporary literary theories is grounded in the conviction that literature and culture shape and co-create space in which man lives. Real, imagined and individually appropriated places or spaces are not precisely delimited. Intermingling, they create lieux d'imagination, ${ }^{2}$ in which topography and existence, life and literature, biography and autobiography come inextricably merged. ${ }^{3}$

Delhi: A Novel by Khushwant Singh (1915-2014) appeared in 1990. Its author was a renowned English-language journalist as well as a successful and prolific writer. ${ }^{4}$ The novel portrays the city of Delhi as seen and experienced by men and women over an extended period of time. Various first-person presences in the book epitomise different historical and imaginary figures, such as Tamerlane, the Mughal emperor Aurangzeb, the Persian king Nadir Shah, the Urdu poet Meer Taqi Meer and Bhagmati, the mistress of the main character of the book. They all describe events from their lives which took place in the city. Within the historical narrative the city of Delhi becomes "Delhi" - a fictional place located in its own unique spatiotemporal dimension made out of different accounts which cover a period of approximately six hundred years of the city's history. In the book we encounter more than a dozen characters who tell their life stories. The city's empirical reality becomes multiplied in the narrators' autobiographical stories, veiled by representations of events and figures, filtered through

2 For the coinage 'lieux d'imagination', see S. Reijnders, Places of the Imagination. Media, Tourism, Culture. Farnham 2011, esp. chap. 2.

3 See E. Rybicka, Geopoetyka. Przestrzeń i miejsce we wspótczesnych teoriach i praktykach literackich [Geopoetics. Space and Place in Contemporary Theory and Practice of Literature], Kraków 2014, p. 240 (Horyzonty Nowoczesności, 109). Elsewhere in the book Rybicka notices (p. 34): Etymologicznie topografia jako 'topos graphos' - opis przestrzeni - ma solidniejsze uzasadnienie na gruncie literaturoznawstwa [...]. [T]opografia wspótgra bowiem z przeświadczeniem o literackim i kulturowym wytwarzaniu przestrzeni [Etymologically topography as 'topos graphos' - description of space - is better substantiated within the realm of literary studies [...]. [T] opography tunes in better with a conviction about literary and cultural construction of space].

4 In his long career as a journalist and writer K. Singh has written, edited, or translated over eighty volumes, a substantial number of short stories, and countless articles for magazines and newspapers. See P. Brians, Modern South Asian Literature in English, Westport, CT 2003, p. 47 (Literature as Windows to World Cultures). More on life of the author see P.K. Varma, 'Face to Face: Khushwant Singh speaks to Pavan K. Varma' in K. Prasad (ed.), Khushwant Singh. An Icon of Our Age, New Delhi 2000, pp. 2-21. 
their emotions and experiences, embedded in narrated lives. As the narrative develops the striking association of the city with Bhagmati, the hijra, ${ }^{5}$ who never speaks in her own voice (contrary to all remaining fictional presences), becomes more and more clearly pronounced. Both the city and Bhagmati are used and abused, they adopt different forms in order to survive and they become transfigured to the point of non-recognition. Yet their mutilations and transfigurations do not influence the core of their self-identity.

The manner in which Delhi is fictionalized within each separate story is not the only way it reveals itself to the reader. In every individual act of reading with its infinite variables, the novel-city is re-created anew by the reader located in his or her own culturally shaped space. Within different zones of the text and of the paratext some of the book's constituent parts may be brought to the fore, while others may remain in the background. If the novel is at first approached as an artefact with different layers or stratifications formed both by the text and in the zone of the paratext, then different pre-reading formations of readerly expectations are emphasized. All of these influence the totality of the reading experience. ${ }^{6}$

This paper is an attempt to analyze the novel of Khushwant Singh not only as a literary work in which topography and existence, life and literature entwine, but also to include in the analysis the paratext, which co-creates the particular horizon of expectation for the reader, the preliminary understanding of 'what the book is about.' The essay is tripartite. In the part entitled Indeterminate zone the analysis concentrates on the outside of the novel, the 'not-yet' of the book, its 'vestibule," which can channel readers' anticipation of the book's content in a specific direction. Particular attention will be paid there to the author's foreword and the titles of chapters. In the second part, Zone of the City, the image of Delhi in its chosen (re)constructions, and specifically also the reconstruction of space and time within the novel, will be examined. The last section of the paper, Zone of the Body will speak of the body and the symbolic roles it plays within the novel.

\section{INDETERMINATE ZONE ${ }^{8}$}

\section{Author's Foreword}

It took me twenty-five years to piece together this story spanning several centuries of history. I put in it all I had in me as a writer: love, lust, sex, hate, vendetta and violence - and above all, tears - confesses Khushwant Singh in a half-page foreword to the first edition

See footnotes 18 and 19 below.

6 See G. Genette, Paratexts. Thresholds of Interpretation, trans. by J.E. Lewin, Oxford 1997.

7 See footnote 8 .

8 See G. Genette, 'Introduction' to Paratext (Paris, Seuil 1987), trans. M. Maclean, New Literary History, Vol. 22, No. 2: Probings: Art, Criticism, Genre (1991), pp. 261-272. 
(1990) of his book. Terse as the fragment is, it gives space for some interpretation. If what the writer confesses is true, then one learns that the novelist's real and the city's fictionalized timelines run together for a considerably long period of his life. A quarter of a century is not much for the city, yet it is one third of an average lifespan of man. The reader of the foreword realizes from the outset that the novelist's life develops along the life of the city his work describes.

When Khushwant Singh declares that, as a writer, he put in the novel all he had in him: love, hate, vendetta and violence, he may be well referring to the pains of creative process, during which - particularly if it lasted for as long as twenty-five years - the process of writing can generate emotions much fuller in range and broader in scale. This cannot be and, indeed, is not what the author seems to refer to here, however much one might like the idea. In the whole unbroken string of words: love, lust, sex, hate, vendetta and violence - and above all, tears, one can see three groups of ideas. Love-lust-sex series seem to be opposed to hate-vendetta-violence, at least when it comes to the their elementary natures. Intuitively, one makes a distinction between the positive feeling of love and the negative feeling of hatred. Yet, even if it is a platitude to say that love-lust-sex and hate-vendetta-vengeance can mingle and influence each other's natures, they still remain forces that sometimes irreversibly bind peoples' fates.

The short sentence of the foreword finishes with a phrase: and above all, tears. Two groups of ideas enumerated earlier in the sentence are joined together to be all understood as reasons for tears - the outer sign of sadness, misery, despair or unhappiness, but also of joy, happiness and highest elation.

From the beginning, then, Delhi: A Novel is revealed as a work embedded in human instincts, sexual drives, violent, sometimes uncontrollable, emotions, and the need to satisfy desires. It is shown to reflect and at the same time to become a reflection of individual lives as they are driven and shaped, founded on and destroyed by the strongest forces to be found in man.

\section{Table of contents}

There are twenty-one chapters in the book and sixteen take their titles from personal names. There are five exceptions: the first chapter is titled 'Delhi', another three: 'The Untouchables,' 'The Builders, 'The Dispossessed' and a single one is a date: '1857.' The remaining chapters bear personal names as their titles: 'Lady J. H. T., 'Musaddi Lal', 'The Timurid,' 'Aurangzeb Alamgir: Emperor of Hindustan,' 'Nadir Shah,' 'Meer Taqi Meer' and 'Bhagmati' - this last name, Bhagmati, serving as the title of no fewer than ten separate chapters. Some are the names of historical figures: the Timurid is Timur (timoor') or Tamerlane (tăm'urlān) - the most famous Turkic conqueror of the fourteenth century; Nadir Shah is the ruler of Persia who sacked Delhi in 1739. One chapter is devoted to the life of the famous eighteenth-century Urdu poet Meer Taqi Meer, another to a certain lady identified as Jane Hoity-Toity. The most conspicuous, because of its frequency, is the name Bhagmati, the mistress of the fictional present-day story narrator Singh. 


\section{Motto}

\section{I asked my soul: What is Delhi? \\ She replied: the world is the body and Delhi its life.}

These lines, used as a motto guiding the reader into the novel, are taken from the work of Mìrzā Asadullāh Khān Ghālib, who was born in 1797 in Agra and died in 1869, in Delhi. ${ }^{9}$ The couplet is simple in its structure. The world, equated here with the body, is juxtaposed against the city, identified with life. These metaphorical identifications create an image of the organic whole, in which the sustenance of the world-body depends on the city - its life, the principle of its animate existence. The body of the world would turn into dead matter if the city were not its life-giving factor. As long as the life inhabits the body, takes possession of it, the body remains alive. The topographical boundaries of the universal, life-giving city are marked out by the limits of the world in which the city is embodied. Delhi is everywhere and everywhere is Delhi - the zone of the urban space transcends its mapped boundaries. In Ghālib's poetic image, the limitless space of Delhi seems to go directly against the etymological sense of "city." Derived from the Proto-Indo-European root kei- 'to lie; bed, couch; homestead; beloved, dear'10 the word speaks of a fixed place, of being enclosed in space, walled from the outside world. Pur, of Sanskrit origin, which can be seen as the last member of some compound names of Indian cities (Jaipur, Manipur), covers two sets of meanings. Pur is a wall, stronghold, fortress, castle, but also the body 'considered as the stronghold of the man (purusa) $){ }^{\prime 11}$ In addition, Sanskrit pur is a feminine noun, and as such it accords well with the archetypal symbolism of the city seen by Jung as a mother-symbol and as a symbol of the feminine principle in general. ${ }^{12}$ Interpreted by Jung as a woman who shelters her inhabitants as if they were her children, ${ }^{13}$ the "city" is that which is beloved, consonant with the PIE derivational basis of the word as well as with the image from Ghälib's distich, in which the city of Delhi is life itself, held dear by all. The Sanskrit pur, however, conveys the sense of both a fortress and the body as a stronghold of the man, and in this way the image of the woman-city and the image of the body of man merge into one and the distinction between the masculine and the feminine principles

M.A.K. Ghälib was a preeminent classical Persian and Urdu poet of the $19^{\text {th }}$ century and the last of the great poets of the Mughal empire who believed that the depth, complexity and variety of his ideas could be conveyed only through Persian words. See M. Alam, 'The Culture and Politics of Persian in Precolonial Hindustan' in S. Pollock (ed.), Literary Cultures in History. Reconstructions from South Asia, New Delhi 2004, pp. 167-168 (Philip E. Lilienthal Book).

10 See: D. Harper, 'City' in Online Etymology Dictionary, 2001-2015, at <http://www.etymonline.com/ index.php?allowed_in_frame=0\&search=city\&searchmode=none >, 2 April 2015.

11 Sir M. Monier-Williams, A Sanskrit-English Dictionary. Etymologically and Philologically Arranged with Special Reference to Cognate Indo-European Languages, new ed., greatly enl. and improved with the collaboration of E. Leumann, C. Capeller and other scholars, repr. Delhi 1986, p. 635.

12 J.E. Cirlot, A Dictionary of Symbols, trans. by J. Sage, London 2001, p. 49.

13 Ibid. 
in the image becomes blurred. That blurring is appropriate to the persona of Bhagmati, who, as will become clear, is the epitome of Delhi.

\section{ZONE OF THE CITY}

The first chapter, entitled: 'Delhi' introduces three main characters of the novel - an elderly man, his mistress Bhagmati and the city. The man, whose autobiographical account rooted in the fictional present time describes his tempestuous love for Bhagmati, is a Sikh. ${ }^{14}$ In the second chapter, 'Lady J. H. T., he identifies himself by the surname Singh. ${ }^{15} \mathrm{He}$ is a well-educated person, a writer or a journalist, with friends among journalists, photographers and politicians. Yet nowhere in the novel is his first name mentioned. He returns to Delhi after travel abroad:

To the stranger Delhi may appear like a gangrenous accretion of noisy bazaars and mean-looking hovels growing round a few tumble-down forts and mosques along a dead river. If he ventures into its narrow, winding lanes, the stench of raw sewage may bring vomit to his throat. ${ }^{16}$

Immediately after that realistic and repellent portrayal of the city there follows a paragraph which describes Bhagmati:

It is the same with Bhagmati. Those who do not know her find her unattractive. She is dark and has pock-marks on her face. She is short and squat; her teeth are uneven and yellowed as a result of chewing tobacco and smoking beedis. Her clothes are loud, her voice louder; her speech bawdy and her manners worse. ${ }^{17}$

The narrator's lover Bhagmati is a hijra by birth: that is, a person born with ambiguous genitals. ${ }^{18}$ In India, the hijras are variously labelled as: eunuchs, transvestites, homosexuals, bisexuals, hermaphrodites, androgynes, transsexuals, and gynemimetics; [...] they are also referred to as a people who are intersexed, emasculated, impotent, transgendered,

14 That becomes clear in the short scene from the chapter 'Delhi' when he overpays for the taxi ride which brought him home from the airport. The taxi-driver is a Sikh and has a Sikh companion with him. See K. Singh, Delhi: A Novel, New Delhi 1990, p. 4: One Sikh may argue with one Sikh. One Sikh must never argue with two Sikhs - certainly not after dark.

15 Ibid., p. 16: 'Your Ladyship has Delhi's worst unpaid guide at her service.'

'You are a joker! We'll get on. My name is Jane. What's yours?' she extends her hand. Bony, strong, cold.

'Singh. A very distinguished name shared by fifty million Sikhs, Rajputs, Banias, Thakurs, Gurkhas, Biharis and many others.'

16 Ibid., p. 1.

17 Ibid., p.1.

18 G. Reddy, With Respect to Sex. Negotiating Hijra Identity in South India, Chicago 2005, p. 237, n. 12: Hijra is an Urdu word, though its etymology is traceable to Persian, either from the root word "biz" meaning 'effeminate, or from hich, for a person who is hichgah nowhere. On p. 243, n. 2 Reddy adds that the term hijra is used more often in the north of India, whereas in the south kojja is preferred. See also Delhi, p. 28: Bhagmati was born in the Victoria Zenana Hospital near Jamia Masjid. When her father asked the doctor, 'Is it a boy or a girl?,' the doctor replied, 'I am not sure.' Throughout the novel, the word hijra is spelled hijda. 
castrated, effeminate, or somehow sexually anomalous or dysfunctional. ${ }^{19}$ The list tellingly illustrates the confused perception of the hijra in contemporary India, though the idea of a human or a divine person, in whose body the male and the female harmoniously join together, has been present in Indian culture from ancient times. ${ }^{20}$ Delhi and Bhagmati attract the narrator, but not out of mere, still less unhealthy, curiosity:

What you have to do for things to appear different is to cultivate a sense of belonging to Delhi and an attachment to someone like Bhagmati. Then the skies over Delhi's marbled palaces turn an aquamarine blue; its domed mosques and pencil-like minarets are spanned by rainbows, the earth exudes the earthy aroma of khas, of jasmine and of maulsari. Then the dusky Bhagmati glides towards you swaying her ample hips like a temple dancer; her mouth smells offresh cloves and she speaks like her Imperial Majesty the Empress of Hindustan. $^{21}$

Fascination with the hijra and the city does not transform the way they are perceived. It is a sense of belonging and an attachment to both rather than an open-minded acceptance that ultimately lead to the change in how the narrator comprehends them. It is the loving attachment that transforms into real affection his original confusion and strange attraction to the hijra, whose ambiguous nature transgresses normative categories of sexuality. But what is there in the nature of Delhi, which may appear like a gangrenous accretion of noisy bazaars and mean-looking hovels growing round a few tumble-down forts and mosques along a dead river ${ }^{22}$ that gives the same emotional effect? This description apparently fits in with Old Delhi. When the British decided to shift their capital from Calcutta (now Kolkata) to Delhi in 1911, they began constructing New Delhi ${ }^{23}$ to the south of what is now known as Old Delhi. The New Delhi of British India was designed as a modern European city, with one main city axis running from the President's Estate to the National Stadium, regular road system with roundabouts from which extends the net of multidirectional branches of roads, openness of space and vast green grounds of a common public space. The plan was to reflect the idea of the garden city developed by the English architect Ebenezer Howard around the time when Edwin Lutyens drew his plans of New Delhi. ${ }^{24}$ For Howard, the garden city was a combination of town

19 V. Lal, 'Not This, Not That: The Hijras of India and the Cultural Politics of Sexuality', Social Text, No. 61: Out Front: Lesbians, Gays, and the Struggle for Workplace Rights (1999), p. 119.

Ibid., p. 326: Lutyens was a man of vision. Although neither he nor Baker had too great an opinion of our old palaces, mosques and temples, they agreed to give an Indian touch to their designs. What impressed me most about Lutyens was that even before roads were laid, he ordered trees to be planted along the proposed routes. A huge nursery was set up to raise the right kind of saplings. Lutyens wanted slow growing but massive, long-living trees like banyans, neems and tamarinds. The official horticulturist imported some exotic trees like the Sausage and the African Tulip tree from East Africa. Lutyens talked of designing a city which would meet the needs of its citizens for two hundred years and forecast that one day the English would leave India and let Indians manage their own affairs. 
and country that would attract people by incorporating the best of both: beauty of nature and social opportunities; pure air and water combined with good drainage; bright homes and gardens without smoke or slums. The result would be an ideal urban space promoting civic well-being. ${ }^{25}$ Old Delhi seems to be its contradiction. It is closed within its ramparts; the Red Fort is its dominant structure. City walls and the fort enforce within its closed space - the arrangement of the basic network of major streets. They, in turn, spread out in a maze of narrow and meandering roads, and culs-de-sac. All these form an intricate matrix that renders much of Old Delhi accessible only to pedestrian traffic $^{26}$ Modern Delhi comprises both New and Old Delhi and it is the all-encompassing whole which challenges the onlooker's ideas of order, design, urbanity. The metropolis escapes definite determination - it absorbs, adopts and appropriates all within its living organism. The city space creates an organic whole which embraces the meticulously planned and spacious garden city of New Delhi and the irrepressible, uncontrollable and claustrophobic chaos of Old Delhi and so it shows as a combination of both nature and culture, ${ }^{27}$ though not in the manner envisioned by Howard. The two cities developed in their own ways and with time they became reconnected, against the construction plans of New Delhi according to which Old Delhi was to be excluded from the modern capital city space designed according to the utopian model of a European visionary architect. Present-day Delhi brings about epistemic shock and enforces reformulation of one's perception of the city as such. The all-encompassing Delhi denies the simplicity of nature-culture differentiation in a manner analogous to the body of the hijra Bhagmati.

The idea of the city embodied in Delhi is closer in its form to the meaning of the Sanskrit feminine noun pur, which is both the fortress and the body as a stronghold of man and in which the image of the woman-city and the image of the body merge in one. In that image the cultured and re-constructed organism of Delhi transforms the perception of the onlooker, so that the skies over Delhi's marbled palaces turn an aquamarine blue; its domed mosques and pencil-like minarets are spanned by rainbows. Likewise, the attachment to the hijra Bhagmati, whose sexuality is undetermined, also transforms both the lover and the nature of the loved one.

From the reader's point of view, Delhi: A Novel is a narrative rooted in two fictional chronologies: the past and the present. In each separate chapter one individual story is told. The stories do not intertwine and what connects them is the geographically defined and fictionally constructed space of the city. Both historical and autobiographical accounts are narrated not in chronological but in spatiotemporal order.

25 See 'Howard-three-magnets', Wikipedia Commons, at <http://commons.wikimedia.org/wiki/ File:Howard-three-magnets.png\#/media/File:Howard-three-magnets.png>, 28 April 2015. Since its inception, the idea of the garden city developed into a "garden city movement," which became very influential all over the world.

26 See V. Ram, 'Delhi' in Encyclopaedia Britannica, at <http://www.britannica.com/EBchecked/topic/156501/Delhi>, 28 April 2015.

27 See T. Sławek, 'Akro/Nekro/Polis: wyobrażenia miejskiej przestrzeni' [Acro/Necro/Polis: Representations of Urban Space] in A. Zeidler-Janiszewska (ed.), Pisanie miasta - czytanie miasta [Writing the City - Reading the City], Poznań 1997, pp. 15-16 (Studia Kulturoznawcze, 9). 
New Delhi

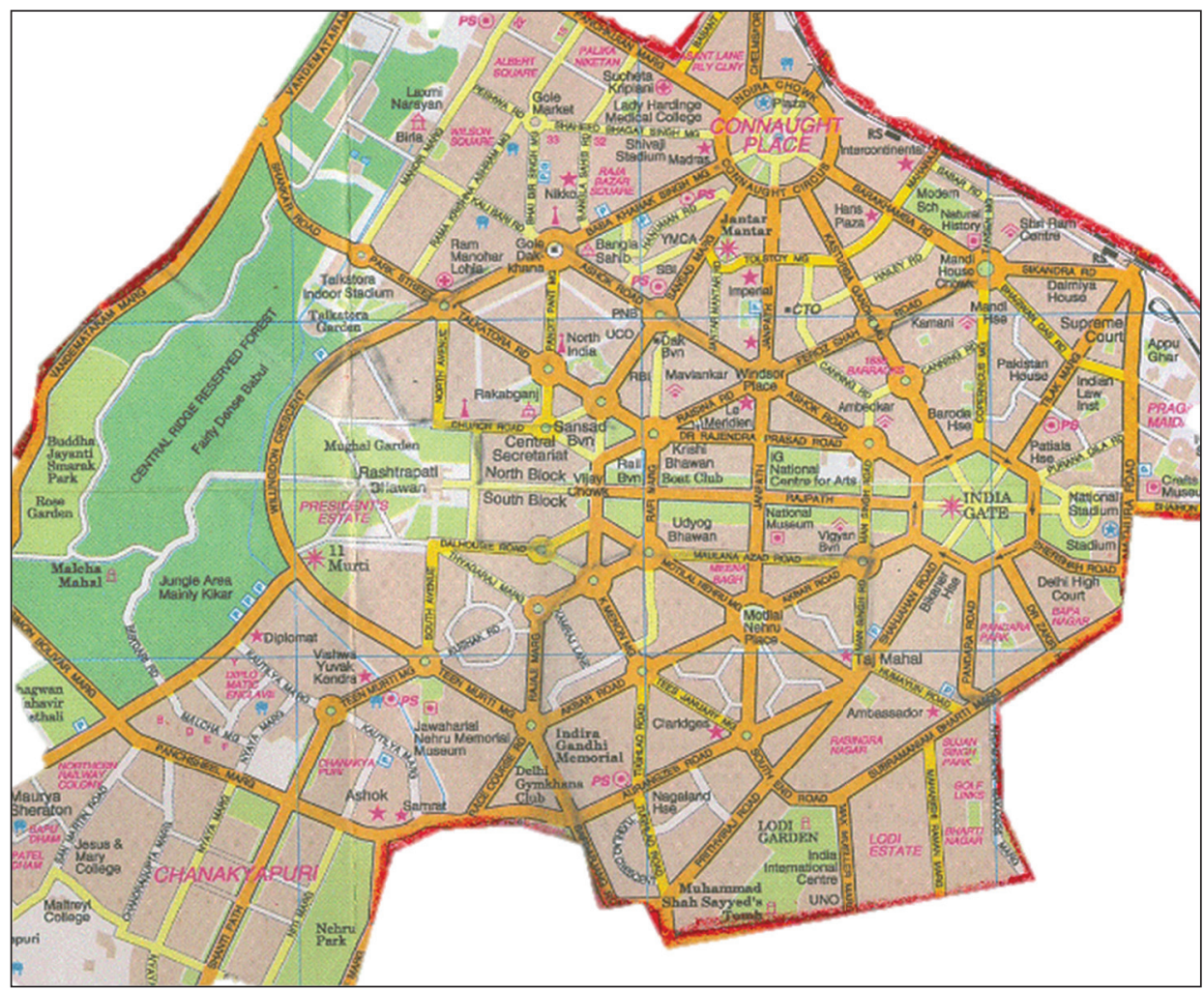

<http://dcnewdelhi.delhigovt.nic.in/images/ndmap.gif>, 4 April 2015

There are two separate circles of narration, which are, to a major part, developed independently. One circle is set in the past and the other in the present. The first one consists of accounts of historical personages or of ordinary people who got entangled in the history by accident. The narrators, among them the poet Meer Taqi Meer, the emperor Aurangzeb Alamgir, the conqueror Tamerlane or the representative of the Indian dispossessed are either the main actors or eye-witnesses to the events. Their stories cover the period of approximately six hundred years, from 1398 when Tamerlane, here Timur the Lame (Timur-e Lang ${ }^{28}$ ), began his invasion of India to eventually conquer Delhi, to the murder of Mahatma Gandhi, related by a refugee boy ${ }^{29}$ who came to Delhi with his

28 Delhi, p. 96: [W] came to be given the name Taimur. Our horoscope had promised that we would be superior to all monarchs of the age, we would protect religion, destroy idols and be the father of our people. At twenty-seven an injury caused a deformity in our foot compelling us thereafter to be more in the saddle than on foot. We knew that behind our backs, common people called us Taimurlang (Timur the Lame) but in our presence they addressed us as the Uncompared Lord of Seven Climes and the Lord of Fortunate Conjunction.

29 Ibid., p. 374: And then everything happens so quickly that I have to go over it again and again to make sure I really saw it happen. A stout, young fellow muscles his way through the crowd, pushes aside a girl who tries 
parents from the Hadali village in Punjab. The second circle of narration is told by the character of the writer Singh who tells the reader about the time he was a guide to the city of Delhi and who also describes his complicated relationship with Bhagmati and with Delhi. This one is a private history taking place in the fictional present. ${ }^{30}$

All the events of the two cycles are related in the first-person singular or the first-person honorific plural. As the story in any given autobiographical account develops, the reader is drawn into the novel's spatiotemporal dimension, observing the events through the eyes of the narrator and understanding them as the narrator does. By so entering into - or merging with - the narrator's consciousness, the reader becomes a participating presence: both the doer and the witness to what happens.

\section{Old Delhi}

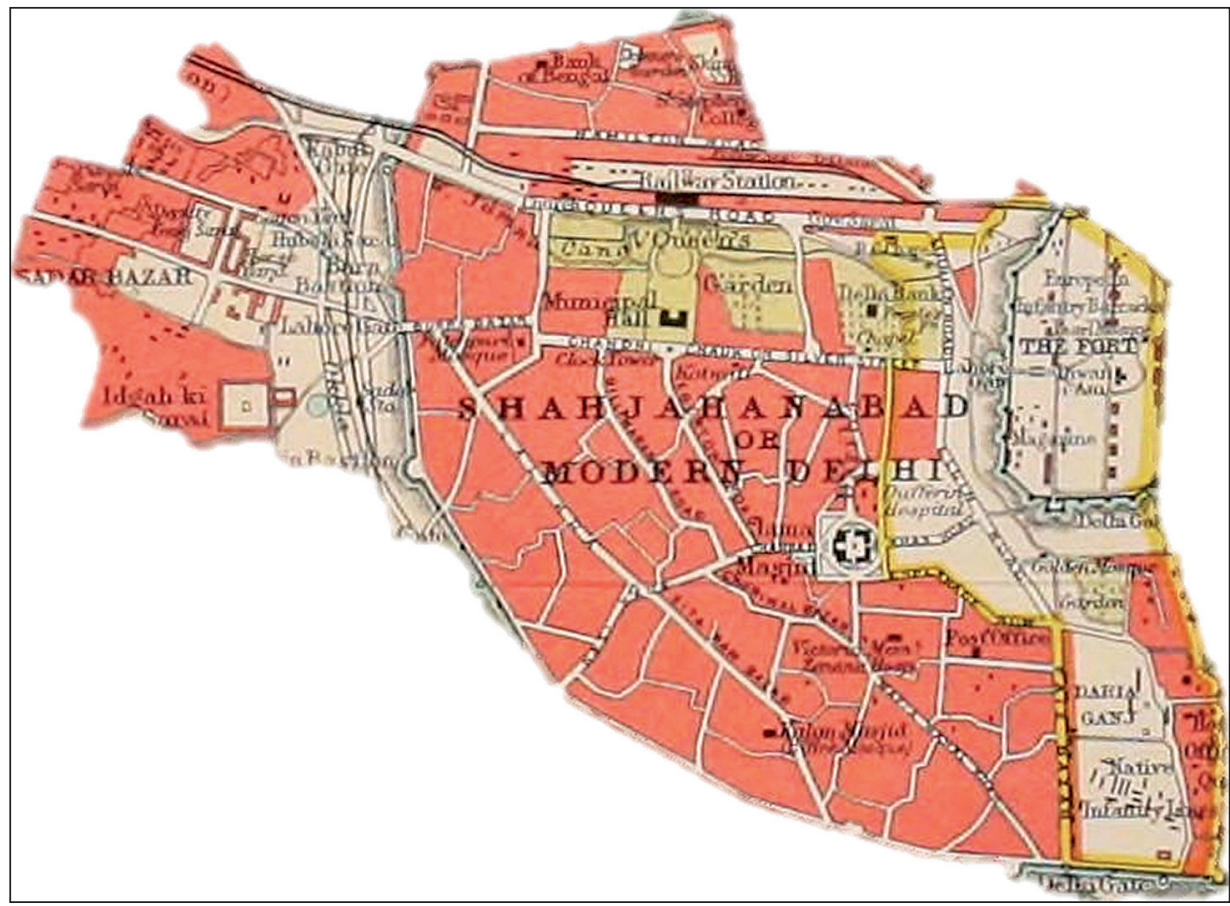

<http://commons.wikimedia.org/wiki/File:Shahjahanabad_or_Modern_Delhi_1911_map.jpg>, 4 April 2015

to stop him, bends down as if to touch Gandhi's feet, draws a revolver from the fold of his dhoti and before anyone can guess what he is up to pumps three bullets into the Old Man, thah, thah, thah. Gandhi's hands remain joined as if he is bidding namaskar to the world. He says, Ram, Ram. Then he crumples down in a pool of his own blood.

30 Ibid., p. 107: It had been a bad year for me. I didn't have many writing assignments and the articles I sold to Indian papers did not get me enough to keep me in the style I was accustomed to. So I registered myself as a guide with the Tourist Department of the Government of India and left my card at foreign embassies and international organizations. 
The two circles of stories are consistently narrated separately and alternately. They are not internally interrelated except for the introductory chapter 'Delhi,' in which the three characters of the ageing writer Singh, his mistress Bhagmati and the city of Delhi are introduced, and the last chapter 'Bhagmati', in which the history of the old man personage intertwines with tragic events on a major historical scale: specifically the 1984 murder of the Prime Minister Indira Gandhi.

All first-person narratives personalise the city. The quasi-autobiographies are intimately related to individual narrators whereas all events described are located in, or associated with Delhi. The trajectories of individual fates cross in one place at different time and lives are altered and shaped by experience of the city. Some narrators see Delhi as the centre of their world, ${ }^{31}$ others locate it at the peripheries of their own world. ${ }^{32}$ For the figure of the aging writer, however, Delhi remains the centre of his world and different places he visits during his travels abroad remain peripheral to him.

Yet Khushwant Singh's novel not only exemplifies how, in each narrative, the autobiographical "I" constitutes the net of geographical interferences ${ }^{33}$ but also how it becomes a meaningful constituent of the history of the place. The city also gives meaningful shape to the individual identities of its inhabitants, invaders, visitors and colonisers: of all those who enter and have their lives changed by it.

In the whole novel the real and the imagined city of Delhi is re-created and re-constructed with and within each separate story told by its protagonist whose individual, finite fate intermingles with the story of the "eternal city" of Delhi which, in turn, embraces all the individual stories and feeds back on them.

\title{
ZONE OF THE BODY
}

\author{
My smell \\ my nakedness \\ entices \\ bordes of buman flesh \\ from faraway lands \\ traders \\ emperors \\ marauders.
}

Abhay K., Delhi

\footnotetext{
31 Ibid., p. 219: How wonderful life was in the Delhi of those days! People thronged to my home to solicit my opinion on their compositions. Wherever I went people recognized me and praised me; there was not a mushaira in the city where I was not the star performer. [...] The people of Delhi loved me; I loved them and their city. In this way the character of the poet Mir Taqi Mir describes his life in Delhi.

32 Ibid., p. 101: We loaded innumerable elephants and camels with the wealth of Delhi and with thousands upon thousands of slaves in our train began our slow march homewards. [...] A month later we and our victorious armies were back in Samarkand. For the figure of Timur the Lame the centre of the world was Samarkand.

33 E. Rybicka, Geopoetyka..., p. 285.
} 
[I]t is pointless trying to decide whether Zenobia is to be classified among happy cities or among the unhappy. It makes no sense to divide cities into these two species, but rather into another two: those that through the years and the changes continue to give their form to desires, and those in which desires either erase the city or are erased by it.

Italo Calvino, Invisible Cities

The history of Delhi in Khushwant Singh's novel is corporeal: much space is given to sexuality, eroticism, physicality, physiology. Most of autobiographical accounts contain haunting images of atrocities committed to the bodies of its citizens by the invaders, ${ }^{34}$ they speak of the abuse of women, men, children. ${ }^{35}$ Much is said about how bodies are made instrumental, exploited, consumed or manipulated in the making of history. At times one has the impression that the interest in what love, lust, sex, hate, vendetta and violence do to the body - along with the role all these play in writing the history of the city - approaches obsession.

Let us focus here on the figure of the prostitute hijra Bhagmati, whose name recurs as the title of ten chapters of Delhi. Bhagmati is a feminine hijra, ${ }^{36}$ which means that the female in her makeup is proportionately bigger than the male. To the hijra community belong mostly phenotypic men [...] with a variety of sexual dysfunctions and homoerotic desires who subsequently excise their genitalia, a minority are intersexed individuals, orpeople born with ambiguous genitalia, whatever their chromosomal and hormonal makeup. ${ }^{37}$

34 Delhi, p. 101: Guards we had posted at the city gates were slain. We ordered our troops to enter these towns and extend the hand of rapine, to slay every able-bodied man and take his women and children as slaves. For the next ten days our men drenched their swords in blood. There was no count of the numbers killed: some said 50,000 others 5,00,000. Ibid., pp. 270-271: [T] hey dragged the prisoners out of the dungeon and slit the throats of thirty-nine of them including women and children as if they were sheep being sacrificed on Bakr-Id. The royal fountain in front of our palace was full of the blood and corpses of these innocent people. Ibid., p. 285: Sahib, I have seen your people thrust their swords into women's bellies. With my own eyes I have seen children tossed in the air and spiked on bayonets.

35 Ibid., p. 258: I was like a piece of white meat fought over by two brown dogs: snarling, biting, clawing, shoving. So it went all through the long, long, sultry night. By the time one had finished, another had worked himself into a frenzy. And there was that hijda poking his fingers or tongue or whatever else he had. I was drenched with sweat and almost dead with exhaustion. By morning Abdullah and his friends were drained of all the poisonous semen in their vile bodies. They stumbled out singing and yelling obscenities. Only the hijda remained. I lay like a corpse while he tore me up like a dog tears carrion. Ibid., p: 208: Below the roof on which I lay, the woman who had made herself a part of my person was welcoming another man between her parted thighs. She had made me a stranger to my wife without any intention of changing her relationship with her own husband. I felt deserted and betrayed.

36 Ibid., p. 29: The troupe of hijdas adopted Bhagmati. They taught her to sing, clap her hands and dance in the manner of hijdas. When she was thirteen her voice broke and became like a man's. She began to grow hair on her upper lip, round her chin and on her chest. Her bosom and hips which were bigger than a boy's did not grow as big as those of girls of her age. But she began to menstruate.

G. Reddy, With Respect to Sex..., p. 235, n. 2. 
The community of hijras deny binary differentiations in many different spheres: in sexuality, as they are neither feminine, nor masculine and prefer to identify themselves as asexual, ${ }^{38}$ in intimate human relationships, by exploring a range of relations much wider than heterosexual, ${ }^{39}$ in clearly defined and culturally embedded identities; in religion, with their syncretic religious practices which combine the elements of the Muslim and the Hindu traditions ${ }^{40}$ in their propensity to nomadic style of life, their remaining on the margins of society. Themselves sterile, they are considered to have power over the procreative process and their blessings are auspicious, especially for the newly wed and at the birth of a male child.

Indian cultural tradition knows very well the idea of a human or divine person who is endowed with marks of the male and the female sex. One of the representations of Siva is ardhanariśvara: the Lord who is half-woman (ardhanarī). As a result of combining the male and the female in one body, Siva possesses dual sexuality. The Virätaparvan, the fourth book of the epics Mahäbhärata describes life of Arjuna, the Pandava prince and his four brothers on the court of the king Virāta. The Pandavas were expelled from their kingdom after they lost it in the game of dice arranged by the Kaurava brothers, with whom they have blood ties. The Pandavas were obliged to remain anonymous during the thirteenth year of their exile and this is when they stay in Virăța's kingdom. Arjuna disguises as a eunuch and, dressed in woman clothes, he teaches dancing to the ladies of the court. Yet as has been observed by scholars of the Indian epic, ${ }^{41}$ the name Bronanad̄ā/Brhannalā which Arjuna assumes, grammatically a feminine noun, means 'having a large reed', so it is not much of a camouflage for his masculinity. All in all, Arjuna's identity at the period of his stay at the Virāta court is unclear. It is difficult to say whether he disguises as an eunuch/the neuter gender (Skt. sand dhaka), a transvestite or a representative of the third sex (Skt. tritiyam prakrtim). ${ }^{42}$

The motif of the hijra, whose nature denies dualistic distinctions in the matters of sexuality, culturally and historically determined identity, interpersonal relations, religious denominations, in a word - all factors which can be seen as the most powerful determinants of human fate - leads the reader to associating the history of the city with that of man. The identity of the hijra challenges the simplified, dichotomous

38 See ibid., particularly pp. 69-70 and passim.

39 Delhi, p. 30: When men came to expend their lust on hijdas - it is surprising how many prefer them to women - Bhagmati got more patrons than anyone else in her troupe. She could give herself as a woman; she could give herself as a boy. She also discovered that some men preferred to be treated as women. Though limited in her resources, she learnt how to give them pleasure too. There were no variations of sex that Bhagmati found unnatural or did not enjoy. Despite being the plainest of hijdas, she came to be sought by the old and young, the potent and impotent, by homosexuals, sadists and masochists.

40 Ibid., p. 100, 113.

${ }^{41}$ For example by Johannes A. B. van Buitenen (in his The Mahäbhärata, Vol. 3, Chicago 1973), Alf Hiltebeitel (in 'Siva, the Goddess, and the Disguises of the Pandavas and Draupadi,' History of Religions, Vol. 20, No. 1/2 (1980), pp. 147-174, at <http://dx.doi.org/10.1086/462866>), Kathleen Garbutt (in her translation of the fourth book of the Mahäbhärata, New York 2006).

42 See Mahābhārata, Book Four: Virāṭa, trans. by K. Garbutt, New York 2006, pp. 32-33 (2,25) (Clay Sanskrit Library, 25). 
and normative views on sexuality, socially acceptable forms of relationships, religious affiliation and morality. These challenges are then reflected in the nature of the city. The mistress of the old writer Singh becomes the epitome of Delhi: the city, which throughout its history adopts different forms, subjugating itself to the succession of different conquerors, recognising their needs, appropriating their natures and features to the point of mimicry, in order to triumphantly survive and outlive them. The body of Bhagmati is identified with the body of the city - it is on the map of their bodies that many cruel procedures are undertaken with the precision of amateur and self-proclaimed "surgeons." They are raped, hurt, injured, tortured, deformed, but they survive. What is more - they remain irresistibly attractive, though their beauty is not indisputable. Bhagmati becomes the figure who anthropomorphizes the city, in whose individual fate is reflected the fate of the city. Both are cynical, unprincipled, corruptible, yet triumphant in their ability to survive. They let others love them, provoking a grand scale of emotions: from love, passion, tenderness, to lust, anger, hatred, or disgust. The story of Bhagmati symbolizes the history of the city and the history of the city is reflected in the mirror of Bhagmati's fate. Bhagmati is Delhi, Delhi is Bhagmati.

Singh's narrative strategies - making the identity of city and hijra interchangeable and telling the stories of Delhi and Bhagmati in alternate chapters - call up unexpected associations and make the reader understand better the narrator's love for both. It is within one and the same body-space of both the hijra and the city, the body-space which is normatively impossible but definitely constituted in its transgressive existence, that we perceive the beauty and the strength of an unconquerable instinct of survival.

Elsewhere is a negative mirror. The traveler recognizes the little that is his, discovering the much he has not had and will never have. Italo Calvino, Invisible Cities

Ghost towns, such as the famous Fatehpur Sikrił ${ }^{43}$ in India, bring about an uncanny feeling of being dislocated in space and time. Abandoned urban space loses its identity, leaving visitors uncertain and displaced when confronted with space which by definition is meant to be inhabited. A ghost town, regardless of how beautiful its architecture may be, is dead. Fatehpur Sikri, planned by Akbar to be the capital of the Mughal Empire is recalled here to remind us not simply that the city lives through its citizens but, more importantly, that the relationship between the city and its inhabitants - including invaders and visitors - is spatially and historically fluid. People position the city in their cultural spaces and endow it with historicity and the city without peo-

43 Fatehpur Sikri, town in Southwestern Uttar Pradesh state, in northern India, was founded in 1569 by the great Mughal emperor Akbar and abandoned, due to paucity of water, less than twenty years later, in 1586. 
ple becomes a city without historicity and without cultural identity. At the most, it is a beautiful but dead façade, a memento estranged in its own location. The urban space without men becomes nonsensical. It is atopic not because it does not occupy a determined space, but it is such in the very sense of the Greek atopos: out of place, strange, odd, eccentric. Delhi was never deserted, even though in the course of its history, its inhabitants were many times decimated. ${ }^{44}$ Contrasting this living, thriving metropolis with the dead town of Fatehpur Sikri emphasises the intimate bond between the city and its inhabitants.

Within Delhi: A Novel are developed different ontologies of the city and there are as many Delhis in the book as there are accounts of it. The space of "Delhi" reflects the outer space of empirical reality, but the empirical reality reflected in the mirror of fiction does not have its own ontology. The empirical facts, events, real historical figures remain outside the mirrored reality. The mirrored reality has no separate existence in its reflected space only because the historically existing reality remains in its position, in front of the mirror.

In theoretical considerations, the city is often conceived of as a multi-layered text, a palimpsest onto which new histories are inscribed again and again. But the space of the narrated and of the real city of Delhi is not only a parchment, a passive material open to inscription. The real and the fictional city interact with one another. The novel-city of Delhi is a heterotopian space which mirrors the reality. ${ }^{45}$ It reflects and at the same time absorbs the real city. The real Delhi, however, remains in its position in front of its reflection, confronted with its own mirrored existence. The reflected duplicate of Delhi within the novel does not leave the real city untransformed. At the intersections of the real, the imagined and the individually appropriated there arise mimetic realities of the city which are neither here, nor there, neither nature, nor culture, neither these, nor those, neither real, nor imagined, neither private, nor public. Different, incompatible realities intermingle, lieux d'imagination are made present, in which places that exist and places that are written, described (topos graphos), life and literature intertwine, become inseparable in their epistemologically unclear and ontologically undefined statuses, within the heterotopian and heterochronic space of a Delhi, a novel.

44 Delhi, chapter 'The Timurid,' p. 101: For the next ten days our men drenched their swords in blood. There was no count of the numbers killed: some said 50,000 others 5,00,000. Nor was there any measure of the quantities of precious stones, gold and silver taken by our valiant soldiers. Even the humblest of our footmen took over two dozen slaves. The wealth they acquired in Delhi would last our men many generations.

45 M. Foucault, 'Of Other Spaces, Heterotopias' (originally published in Architecture, Mouvement, Continuité, Vol. 5 (1984), pp. 46-49. Cited here from Michel Foucault and Jay Miskowiec, 'Of Other Spaces', Diacritics, Vol. 16, No. 1 (1986), pp. 22-27). Foucault describes heterotopia as follows (p. 25): the heterotopia is capable of juxtaposing in a single real place several spaces, several sites that are in themselves incompatible. He then adds (p. 26) that heterotopias are most often linked to slices in time - which is to say that they open onto [...] heterochronies. 


\section{BIBLIOGRAPHY}

Alam M., 'The Culture and Politics of Persian in Precolonial Hindustan' in S. Pollock (ed.), Literary Cultures in History. Reconstructions from South Asia, New Delhi 2004 (Philip E. Lilienthal Book).

Bajpai R.K., Dixit P., 'Khushwant Singh's Delhi: A Novel as History' in R. S. Pathak (ed.), Indian Fiction of the Nineties, New Delhi 1997 (Creative New Literatures Series, 15).

Bhatt I. (ed.), Fictional World of Khushwant Singh, New Delhi 2002 (Creative New Literatures Series, 53).

Brians P., Modern South Asian Literature in English, Westport, CT 2003 (Literature as Windows to World Cultures).

Chopra R., 'Fiction as Social History: A Study of Khushwant Singh's Novels', IUP Journal of English Studies, Vol. 8, No. 2 (2013).

Cirlot J.E., A Dictionary of Symbols, trans. by J. Sage, London 2001.

Foucault M., Miskowiec J., 'Of Other Spaces', Diacritics, Vol. 16, No. 1 (1986).

Genette G., 'Introduction' to Paratext (Paris, Seuil 1987), trans. M. Maclean, New Literary History, Vol. 22, No. 2: Probings: Art, Criticism, Genre (1991).

Genette G., Paratexts. Thresholds of Interpretation, trans. by J.E. Lewin, Oxford 1997.

Gupta R., 'Humour in Khushwant Singh's Delhi,' The Quest, Vol. 14, No. 1 (2000).

Harper D., 'City' in Online Etymology Dictionary, 2001-2015, at <http://www.etymonline. com/index.php?allowed_in_frame $=0 \&$ search $=$ city\&searchmode $=$ none $>$.

Hiltebeitel A., 'Siva, the Goddess, and the Disguises of the Pandavas and Draupadi', History of Religions, Vol. 20, No. 1-2 (1980), at <http://dx.doi.org/10.1086/462866>.

Jha M., 'The Fictional Technique of Khushwant Singh: A Case Study of Delhi' in K.N. Awasthi (ed.), Contemporary Indian English Fiction: An Anthology of Essays, Jalandhar 1993.

Lal V., 'Not This, Not That: The Hijras of India and the Cultural Politics of Sexuality', Social Text, No. 61: Out Front: Lesbians, Gays, and the Struggle for Workplace Rights (1999).

The Mahäbhärata, trans. and ed. J.A.B. van Buitenen, Vol. 3, Chicago 1973.

Mahäbhärata, Book Four: Virätạ, trans. by K. Garbutt, New York 2006 (Clay Sanskrit Library, 25).

Mathur O.P., 'Khushwant Singh's Delhi - A Gloss on History' in idem, The Modern Indian English Fiction, New Delhi 1993.

Monier-Williams M., A Sanskrit-English Dictionary. Etymologically and Philologically Arranged with Special Reference to Cognate Indo-European Languages, new ed., greatly enl. and improved with the collaboration of E. Leumann, C. Capeller and other scholars, repr. Delhi 1986.

Ram V., 'Delhi' in Encyclopaedia Britannica, at <http://www.britannica.com/EBchecked/topic/156501/Delhi $>$.

Rao P., 'Khushwant Singh's Delhi: Between History and Passion', Indian Scholar, Vol. 15, No. 1 (1993).

Reddy G., With Respect to Sex. Negotiating Hijra Identity in South India, Chicago 2005 (World of Desire). 
Reijnders S., Places of the Imagination. Media, Tourism, Culture. Farnham 2011.

Rybicka E., Geopoetyka. Przestrzeń i miejsce we wspótczesnych teoriach i praktykach literackich, Kraków 2014 (Horyzonty Nowoczesności, 109).

Singh K., Delhi: A Novel, New Delhi 1990.

Sławek T., 'Akro/Nekro/Polis: wyobrażenia miejskiej przestrzeni' in A. Zeidler-Janiszewska (ed.), Pisanie miasta - czytanie miasta, Poznań 1997 (Studia Kulturoznawcze, 9).

Varma P.K., 'Face to Face: Khushwant Singh speaks to Pavan K. Varma' in K. Prasad (ed.), Khushwant Singh. An Icon of Our Age, New Delhi 2000.

Halina MARLEWICZ, Ph.D. - Indologist, Associate Professor at the Institute of Oriental Studies, Jagiellonian University, Visiting Professor at the Ateneo de Manila University in the Philippines in 2013-2014. Her research interests comprise literature, culture, philosophy, aesthetics and literary theories of Classical India, theory and practice of translation from Oriental languages; Polish traditions of research on Orient, Indian literature in English. Author, co-author and editor of books on chosen aspects of Indian culture, literature and philosophy, and books of translations from the Vedic and Sanskrit literature. 